\title{
Chapter 12 \\ The Comparative Analysis of Mass Atrocities and Genocide
}

\author{
Barbara Harff
}

Rudolph Rummel and I are both products of Northwestern University's Ph.D. program - although I graduated 18 years later. ${ }^{1}$ Thanks to him, I already knew something about factor analysis, having read his dissertation. I was equally familiar with arguments about peace among democratic states, because my major was in international relations with a minor in jurisprudence (i.e. international law) and another in comparative studies. The democratic peace argument filtered much later into comparative studies of civil conflict in democratic societies and made much sense to me in theory, the way it became a major focus in Rudy's work on mass death and genocide.

My task here is to assess Rummel's contribution to genocide studies, which has been the focus of my own scholarly career. Twenty years ago, I reviewed Death by Governments critically (Harff, 1996: 117-119) and I will use this book to answer some of the criticism he had to deal with after it was published in 1994. Of course, his work was also hailed at the time as a major contribution because it documented how many people were killed by authoritarian and communist governments in the 20th century. My focus will be first on his definition of democide in comparison with the narrower definition of genocide, second on data issues, and third on some implications of his theoretical focus, mainly his democratic peace argument.

Barbara Harff, b. 1942, is Professor of Political Science Emerita at the US Naval Academy and has been Distinguished Visiting Professor at Clark University's Strassler Center for Holocaust and Genocide Studies. She helped plan the 2004 Stockholm International Forum on the Prevention of Genocide and co-founded with Yehuda Bauer the Genocide Prevention Advisory Network (GPANet.org). Her books include Genocide and Human Rights: International Legal and Political Issues (1984) and, with Ted Robert Gurr, Ethnic Conflict in World Politics (1994, revised ed. 2003); Email: barbaraharff@aol.com.

\footnotetext{
${ }^{1}$ This chapter is based on a contribution to a panel at the 56th Annual Convention of the International Studies Association, New Orleans, LA, 18-21 February 2015.
} 


\subsection{Definitional Issues}

Rudy devoted five books to the systematic analysis of democide, four of them published within a span of five years. Lethal Politics (1990) documented Soviet mass killings after 1917, China's Bloody Century (1991) was the second, and the third covered Nazi Genocide and Mass Murder (1992). The capstone was Death by Government (1994), which summarized the empirical and theoretical basis of his concept of democide, with documentation of many other cases. The fifth book, Statistics of Democide (1998) showed just how thoroughly and carefully he compiled and analyzed the data he used.

Definitions are crucial to a new and broad concept like democide. Rummel (1994: 42) summarizes a chapter-long discussion with this: 'A death constitutes democide if it is the intentional killing of an unarmed or disarmed person by government agents acting in their authoritative capacity and pursuant to government policy or high command'. He adds that it encompasses reckless and wanton disregard for the lives of forced labor and concentration camp victims; 'unofficial' killings by private groups; extrajudicial summary killings; and mass deaths that occurred because governments ignored or perpetrated their causes, as in deliberate famines. Elsewhere (p. 37) he adds that it includes killings by de facto governments, i.e. rebels or warlords. One major category of intentional killing not counted as democide consists of the military casualties of international war. His data show that civilian deaths by government in the 20th century outnumber military deaths by a ratio of about 6 to 1 (pp. 15, 20).

In my review, I pointed out that 'clear conceptualization is a prerequisite to sound explanation' (Harff, 1996: 118). Rudy's definition of democide meets this criterion. Moreover it has both a theoretical and normative basis: he uses it to guide his cumulation of data on mass killings by totalitarian and autocratic government, which he systematically contrasts with the much lower incidence of mass killings by democratic governments. So how does this compare with the concept of genocide and its theoretical uses? Rummel points out that democide comprises genocides, but not all genocidal phenomena as detailed by Raphael Lemkin and codified in the UN's 1948 Genocide Convention. ${ }^{2}$ The Convention includes policies whose intent is to cause mental harm, to inflict conditions of life aimed to bring about the group's physical destruction in whole or part, and measures intended to prevent birth. Specifically, the crime of genocide is the intent to eliminate 'in whole or part' a national, racial, ethnic, or religious group. Insofar as this entails direct killing of group members, it is included in democide. The data collections created to operationalize this definition (for example by Harff, 2003 and Fein, 1993) focus on killings, not on mental or cultural harm. Moreover, the working definitions of empiricists almost invariably include politicide, the killing of people because of their political and social affiliations. Indeed, Lemkin included destruction of a people's

\footnotetext{
${ }^{2} \mathrm{UN}$ General Assembly, Convention on the Prevention and Punishment of the Crime of Genocide, General Assembly Resolution 26, 8 December 1948.
} 
political and social institutions, but the politics of the UN General Assembly precluded inclusion of this type of mass killing, now generally called politicide.

There is an obvious normative purpose to the Genocide Convention and the empirical research carried out in its name: to clarify the causes and manifestations of genocide (and politicide) so that preventive actions are justified, and required, by international law. In short, conceptually democide includes all the mass killings associated with genocide and politicide, but also many others that are not aimed at the intentional destruction of a particular group. And normatively their objectives also are somewhat different. The study of democide leads to condemnation of entire categories of governments because they are at risk of killing large numbers of citizens; comparative study of genocide aims to help identify specific governments for specific crimes against humanity.

\subsection{Data Questions}

Compiling global data is hazardous and will inevitably invite chagrin and criticism from country experts. Case study people have a problem with systematic data because they often think they know better what happened in one particular country. I have sympathized with this view, because my area expertise was the Middle East. But when empiricists focus on global data, we have to consider 190 countries and must rely on country experts selectively. When we look for patterns and test explanations, we cannot expect absolute precision, in fact we do not require it.

In my critical review I said that 'from an empirical viewpoint, there are problems with Rummel's data', that is, 'he chooses numbers of death that almost always are skewed in the direction of the highest guesses' (Harff, 1996: 118). The most damaging critique came from an anonymous blogger, who argued that Rummel had no business writing a book on a subject matter that he did not master. Five books seem to me sufficient evidence of mastery, if not necessarily total accuracy. That is in fact an inevitable problem for those seeking reliable data on mass casualties. Few perpetrators make accurate counts of their victims. Estimates diverge widely, and Rummel is careful to gather and report multiple estimates for any given event. Thus, his detailed writings refer to ranges of estimates, but rather than repeat them at every turn he usually uses average or median numbers. Then he adds them for total effect: '169,198,000 Murdered' (the title of Chap. 1) globally from 1900 to 1986. Later he enlarged this to 262 million, after increasing the figure for colonial democide and concluding that the deaths due to the Chinese famine of the Great Leap Forward in 1959-61 were an intentional consequence of government policy. ${ }^{3}$

Another reason for being critical about the democide data was that Rummel could have provided more useful datasets by focusing specifically on more precisely defined concepts such as geno/politicide, mass atrocities, ethnic wars, or state

\footnotetext{
${ }^{3}$ See at: http://www.hawaii.edu/powerkills/20TH.HTM.
} 
terrorism. All of these specific types of state-implicated violence have been the subject of comparative empirical studies aimed at identifying their causes. The concept of democide is so wide that it is inevitable that Rudy's numbers of death are higher than those for genocide specifically.

A third critique comes from case study scholars who may argue that one should pay attention to additional episodes that did not make a particular list, or that numbers of people dead were higher, lower or altogether too badly documented to warrant any reasonable estimates. As someone who had tried to identify all cases of geno/politicide since World War II, ${ }^{4}$ I fully understand what it takes to collect reliable, unimpeachable global data. It is impossible. The best we can do is to seek advice about additional episodes, and to report ranges of fatality estimates, as Rummel does.

Over time I have become more critical of country experts who challenge systematic empirical studies. Case studies are scarce, of dubious accuracy, or non-existent for some episodes of mass death, and estimates vary greatly. Some episodes dating back to before say, 1918 happened in countries that no longer exist or in countries that did not yet exist. Colonial authorities in Africa and Asia kept scarce or no records of birth or death rates. Perpetrators seldom keep records of their misdeeds and if they do, as in Nazi Germany, death estimates often are greatly underestimated or attributed to circumstances rather than deliberate policies.

To make the point clearer, let us take a closer look at two 20th century episodes of genocide. Who among scholars is correct in estimating the numbers who died during the Holocaust? If we treat the Shoah as genocide, we count as its victims about 5.5 million people-Jews, Roma, and others - who were killed because of their ethnic, racial, religious, or national group affiliation. What happened to the others who died, because of their political affiliations, or were systematically starved (see especially Russian prisoners of war) or were victims of what today we would call crimes against humanity during war, i.e. atrocities? Should we ignore the deaths of millions because of some arbitrary definition? The concept of democide avoids this essential problem. By Rummel's estimates 20,946,000 died at the hands of Nazi Germany from 1933 to 1945, of whom 16,315,000 were victims of genocide (Rummel, 1994: 4).

For another more recent example, consider Cambodia (1975-79). Some scholars argued that under the Genocide Convention it was not a genocide, because the victims belonged to the same ethnic group as the perpetrators. Senseless as it may seem today, it became an issue because of the primary focus on the group identity of victims. This led these scholars to think that victims had to be the 'OTHER,' some identifiable group apart from the perpetrators, although the language of the convention never says that genocide cannot be committed by people who are ethnic, racial, national, or religious kin of the victims. If we follow that logic, Germans killing Germans during World War II or Khmers killing Khmers in Cambodia cannot be counted as victims of genocide. In the case of Cambodia, the concept of

\footnotetext{
${ }^{4}$ Harff \& Gurr (1988) and many revisions through Harff (2003).
} 
'auto-genocide' became part of some scholars' definitional arsenal. The concept of democide avoids this conceptual trap.

Any internal conflict situation carries the seeds of genocide. We know that typically victims have multiple identities, thus gender, culture, economic and social status, and political affiliation may play a secondary or close to a primary role in their victimization. Genocidal patterns often are readily apparent. In the search for motives and intent we should analyze killing patterns. Thus in the case of Cambodia intent is not hard to discover. What seemed irrational to outside observers such as killing loyal cadres, makes sense when one took a close look at the confused ideology of the Khmer Rouge. This was an ideology reminiscent of Jacobinism, a revolution that devoured itself. Many victims were simply not wanted by the regime for diverse reasons that changed over time.

I chose to call this genocidal episode a politicide, having coined the concept to account for victims who were killed primarily because of their political or social affiliations. I used estimates from various sources that ranged from 1.9 million to 3 million people killed in four years of Khmer Rouge rule of a population of about 7 million.

Later, I came across a demographic study conducted by the CIA suggesting a likely death toll of 1.2-1.3 million dead and I lowered my estimates. In general, I think it is necessary at first look to assume higher death rates, because the perpetrators are unlikely to tell and demographic data in poor third-world countries are of questionable accuracy. When I looked at Rudy's sources for Cambodia I recognized all (for example Chandler, 1991, and Kiernan \& Boua, 1982). I became cautious about trusting these sources, especially when I realized that there was an ideological bent to these scholars who, at least during their early careers, seemed to be apologists for the Khmer Rouge regime. Rummel, in his analysis of Cambodia, categorizes deaths from 1967 to 1987 as caused by war and rebellion (514,000), famine and disease $(280,000)$ and democide $(3,186,000)$. Given that he includes all victims of government killings, his estimates are consistent with those of others.

Nowhere in Death by Government is it more obvious what drives Rummel to collect data than in the case of Cambodia. He describes the indescribable with great passion and revulsion. I share his sorrow and anger about the cruelty and sheer inhumanity that led to the deaths of the old, the feeble, babies, pregnant women, and so many others. Cambodia at large was a Nazi type concentration camp for all but a few-the Hell State as Rummel calls it. In 1981, I was in Thailand to interview survivors of the Cambodian genocide in a makeshift refugee camp. The detailed descriptions of unspeakable horrors have never left me. I relived it when Rummel described the slaughter of a pregnant woman whose fetus was hanged to wither. For years it haunted me to think that a human being could act as a wild beast and that observers, near or distant, did nothing. As we know all too well, helpers in the real world are a rare breed in the face of danger to their own survival, but then few of us have ever been in such situations. Rummel was enraged by what he heard and saw. This is what drove him to report how, how many, why, and when the victims died. This is the kinship I feel, each death that we report prompts us to mourn a life lost. 


\subsection{Discovering Intent}

Democide according to Rudy, as noted above, 'is the murder of any person or people by a government, including genocide, politicide, and mass murder.' Given his definition, he has to deal with all the issues above and add victims killed during other forms of conflict, such as civil wars and pogroms, in which peoples are murdered by states for any reason, as in Syria today, or during World War II, as were Polish civilians and officers. Rummel adds that the killing has to be intentional not indiscriminate, thus, he is very much in the same position as any genocide scholar seeking to discover intent.

To reiterate, when we count victims of genocide we need to look for groups that have a common identity as described in the Genocide Convention. We also recognize that perpetrators may attribute a collective identity to them of which they may not be conscious - as 'enemies of the state' or 'old people' who stand in the way of social change. By contrast, Rummel includes in democide both geno/ politicide and mass murder, all instances in which governments kill or cause the death of peoples because of their religion, race, language, ethnicity, national origin, class, politics, speech, actions construed as opposing the government or wrecking social policy, or by virtue of their relationship to such people (Rummel, 1994: 3637). These categories of peoples go way beyond the official definition of genocide by the inclusion of class, politics, speech, and kinship. The latter categories could be construed as part of what I call politicide, but kinship is not part of the definition either in the Genocide Convention or in the discussion of political groups. By his definition, victims of massacres include the killings of prisoners of war and captured rebels, an extension that probably is acceptable to most scholars dealing with mass violence.

Intent is a necessary condition for identifying genocide and politicide. Rummel deals with it by arguing that democide includes the targeting of noncombatants during a war or violent conflict out of hatred or revenge, or to depopulate an enemy region, or to terrorize civilians into surrender; also included is torture leading to death. Essentially he includes all intentional killings, but excludes 'actions taken against armed civilians during mob actions, executions for capital crimes and death of noncombatants during attacks where the primary targets are military.' How to discover intent in democide is less complicated than in geno/politicide. In geno/politicide group members are targeted whereas in democide they can be either members of groups or individuals. Thus, in democide it is not a question whether group survival is at stake, i.e. how many people need to be killed to destroy the group in part or whole, because he counts anybody systematically killed by a government.

In the early days of genocide studies we had difficulties with how best to discover intent. I argued that we can be confident that the killings are intentional when we see that a particular group's members are targeted repeatedly and in a sustained campaign. Rummel sees as intentional all killings that are premeditated and carried out by governments or their agents, even if the killings happen through 
malign neglect, such as mass starvation, or through indiscriminate bombings of settlements, as in Syria now. For him, intent is discovered through looking at outcomes. Any action by a government or their agents that leads inevitably to death is likely a case of democide. Today, genocide scholars have less disagreement about discovering intent. Act and outcome matter most. If ISIL members massacre Alawites or Yazidis repeatedly, it is a genocide; here we come close to Rummel's perspective of what matters most.

The perpetrators of genocide and democide include both governments and de facto governments. When I first read of de facto governments I was intrigued by the way Rudy included competing governments, that is rebel organizations that control part of a country. For me, the category government was also too narrow, because in some cases genocide was committed by non-governmental groups acting with an implicit government sanction, as in Sudan and the eastern Congo. I called de facto governments contending authorities, although this leads to real problems with statistical analyses that focus on states as the primary actors.

In one other respect, though, the significance of fatality estimates varies between genocide studies and democide. Genocide by definition is not dependent on numbers of people killed. The destruction of a group is at stake when the leadership is annihilated, which takes the life out of the group. Hypothetically, victims could number in the few hundreds. A case in point is the persecution of Ba'hais by the revolutionary Iranian regime, with a few thousands killed; or Syria where some 30,000 members of the Muslims Brotherhood and other civilians were murdered by the Hafez Assad regime in 1981/82. We need to be able to identify victim groups, and should be able to identify the proportions of people eliminated. But even the death of 30,000 Muslim Brothers is scarcely a blip in the data on democide.

\subsection{Theoretical Issues}

Let me now return to the democratic peace argument. Rudy, like many other scholars, contended that democracies are unlikely to fight each other. Among democracies, diplomacy replaces bullets. Domestically, the ballot box has the same moderating effects. He argues that if we check power through democratic freedoms we would not have democide (Rummel, 1994: 27). Quoting Lord Acton, Rummel (1994: 19) concludes that 'power kills, and absolute power kills absolutely'. This is a categorical statement about a relationship that is in fact probabilistic. A larger theoretical question it raises is why do some totalitarian and authoritarian regimes commit megamurders while others do not? Saudi Arabia, for example, is one of the most authoritarian states in the contemporary world, yet state executions only number in the hundreds. Uzbekistan is a similar example. And on the democratic side, Sri Lanka is one clear case of a democratic regime that in 1989-90 authorized military squads to track down and summarily execute members and suspected supporters of the JVP (Peoples Liberation Party), which had begun its second rebellion that threatened to overthrow the state. Between 13,000 and 30,000 were 
killed in this politicide - not a megamurder, of course, but a challenge to Rudy's basic argument.

A regime's power is a permissive condition, not a root cause of mass violence. Empirical research on causes of genocides and on civil wars has provided much evidence on the preconditions of mass murder. Krain $(1997,2000)$ shows that genocides and politicides often occur in the immediate aftermath of abrupt power transitions, when new leaders suppress their opposition. Valentino, Huth \& Balch-Lindsay (2004) show that 'excess casualties' (including genocidal-like mass atrocities) are most likely to occur in civil wars in which regimes face major armed challenges - an explanation that fits the Sri Lanka example. My research on the preconditions of genocide shows that regimes based on ethnic minorities are particularly likely to use genocidal strategies against majority ethnicities - as in contemporary Syria. My results also show that regimes with exclusionary ideologies often resort to mass killings of opponents (Harff, 2003). Examination of Rudy's list of megamurders shows that the greatest death tolls-notably in Soviet Russia, PRC China, Nazi Germany, and Cambodia - were the result of deadly social engineering aimed at implementing an ideological imperative. But where does this leave us? His data on democide are descriptions in search of multivariate explanation.

In my 1996 review, I characterized Rudy's argument about power and democracy as a categorical imperative and a case of wishful thinking. The implication for international policy is that the best (only?) defense against democide is to encourage democratic transitions. But, then 'not all authoritarian or traditional polities are likely to commit genocide, nor are the local traditions and political cultures of many third-world states necessarily compatible with democratic traditions' (Harff, 1996: 119). We also know that failed efforts to democratize countries have contributed directly to episodes of mass murder and genocide, as in Rwanda and Burundi. My 2003 article reports a test of a structural model of the antecedents of geno/politicide, in which political system characteristics was one of six significant variables. Autocracy and democracy were indexed using the Polity dataset. I found state failure in states with autocratic regimes to be three and a half times more likely to lead to geno/politicides than failure in democratic regimes if they occur in the context of other risk factors identified (Harff, 2003: 66). Rummel was partially correct, but it needed a more careful analysis to evaluate the claim that democracy is a sovereign remedy for democide. He could have tested his claim, recognizing that democracy is a matter of degree, using the Polity data with which he was familiar. But in none of his work, as far as I know, does he report empirical tests of his basic thesis. And perhaps that was unnecessary because the enormity of his democide data collection points unambiguously to the guilt of totalitarian and (some) authoritarian states.

What are we to remember about Rummel? He was a scholar who did a monumental job in collecting data and information, one of the very few scholars of mass murder who was systematic and global in his quest to document genocides, politicides and mass murder, and to identify a root cause. A passionate man, bold and courageous in stating his ideas. He held that liberalism, unabridged political participation, freedom of the press, and an independent judiciary were the best 
guarantees to protect individuals from those who preach that the ideal society can only be achieved through murder, repression, and enslavement. If he were to chronicle the contemporary rise of ISIL or Syria's descent into politicide, he would have thought that humanity had heard nothing.

\section{References}

Chandler, David P (1991) The Tragedy of Cambodian History. New Haven, CT: Yale University Press.

Fein, Helen (1993) Accounting for genocide after 1945: Theories and some findings. International Journal on Minority and Group Rights 1(2): 79-106.

Harff, Barbara (1996) Review of RJ Rummel: Death by Government. Journal of Interdisciplinary History 27(1): 117-119.

Harff, Barbara (2003) No lessons learned from the Holocaust? Assessing risks of genocide and political mass murder since 1955. American Political Science Review 97(1): 75-90.

Harff, Barbara \& Ted Robert Gurr (1988) Toward empirical theory of genocides and politicides: Identification and measurement of cases since 1945. International Studies Quarterly 32(3): 359-371.

Kiernan, Ben \& Chanthou Boua (1982) Peasants and Politics in Kampuchea 1942-1981. London: Zed.

Krain, Matthew (1997) State-sponsored mass murder: The onset and severity of genocides and politicides. Journal of Conflict Resolution 41(3): 331-360.

Krain, Matthew (2000) Democracy, internal war, and state sponsored mass murder. Human Rights Review 1(3): 40-48.

Rummel, Rudolph J (1990) Lethal Politics: Soviet Genocide and Mass Murder since 1917. New Brunswick, NJ: Transaction.

Rummel, Rudolph J (1991) China's Bloody Century: Genocide and Mass Murder since 1900. New Brunswick, NJ: Transaction.

Rummel, Rudolph J (1992) Democide: Nazi Genocide and Mass Murder. New Brunswick, NJ: Transaction.

Rummel, Rudolph J (1994) Death by Government. New Brunswick, NJ: Transaction.

Rummel, Rudolph J (1998) Statistics of Democide: Genocide and Mass Murder since 1900. Muenster: LIT.

Ulfelder, Jay \& Benjamin Valentino (2008) Assessing risks of state-sponsored mass killing. Social Science Research Network, http://papers.ssrn.com/sol3/papers.cfm?abstract_id=1703426.

Valentino, Benjamin; Paul Huth \& Dylan Balch-Lindsay (2004) 'Draining the sea': Mass killing and guerrilla warfare. International Organization 58(2): 375-407. 
Open Access This chapter is licensed under the terms of the Creative Commons Attribution 4.0 International License (http://creativecommons.org/licenses/by/4.0/), which permits use, sharing, adaptation, distribution and reproduction in any medium or format, as long as you give appropriate credit to the original author(s) and the source, provide a link to the Creative Commons license and indicate if changes were made.

The images or other third party material in this chapter are included in the chapter's Creative Commons license, unless indicated otherwise in a credit line to the material. If material is not included in the chapter's Creative Commons license and your intended use is not permitted by statutory regulation or exceeds the permitted use, you will need to obtain permission directly from the copyright holder.

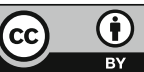

